\title{
Трансформационные процессы в белорусской деревне на рубеже 20-30-х гг. XX в.
}

Аннотация. В статъе анализируются причинъ изменений в аграрной политике большевиков в Беларуси на рубеже 20-30-х г2. ХХ в. Исследуются направленность и содержание трансформачионных прочессов в соииальной сфере и экономическом поведении белорусского крестьянства. Определяются тендениии развития индивидуального крестьянского хозяйства. Рассматриваются особенности рыночного поведения белорусского крестьлнства как фактора свертывания нэпа. Анализируется динамика коллективизачии в БССР, формы, иели и итоги раскулачивания. Уточняются демографические потери в результате голода в белорусской деревне 1929-1933 г2. На основе компаративного изучения анализируются динамика и содержание соииально-политической трансформачии в Беларуси на рубеже 20-30-х г2. ХХ в., ее специфика в сравнении с другими республиками СССР. Историко-генетический метод позволил проследить истоки сочиально-экономических противоречий в белорусской деревне на рубеже 1920-1930-х г2. и их последствия. На основе структурно-функиионального анализа определена направленность трансформачионных прочессов в белорусской деревне в межвоенный период. Сделан вывод о том, что развитие индивидуального крестьянского хозяйства во второй половине 1920-х гг. столкнулось с существенными трудностями, выразившимися прежде всего в уменъшении товарности сельскохозяйственного производства. Если индивидуальное крестьянское хозяйство выявило тендениию к увеличению потребления, то через колхозную систему выкачиваласъ даже та часть хлеба, которая была необходима для выживания крестьянской семъи. Это привело к массовому голоду в БССР и явилосъ одним из важнейших факторов замедления роста численности населения в первой половине 1930-х г2. В 1933 г. (впервые за время после окончания Первой мировой и гражданской войн) произошло снижение численности населения БССР. В своих стратегиях выживания белорусское крестьянство продемонстрировало солидарность, которая не определялась партийной принадлежностью и сочиальной иерархией. Развитие образования, увеличение числа выходчев из деревни в вузах в 1920-е г2. способствовало росту прокрестьянских, белорусских настроений, что в числе других факторов предопределило ряд политических прочессов в Беларуси на рубеже 20-30-х ге. ХХ в.

Ключевые слова: демографические прочессы, советская модернизачия, аграрная политика, коллективизация, продовольственная безопасность, рыночный тип поведения, сочиальная психология, модернизация, белорусская деревня, трансформачионные прочессы.

Abstract. The article analyzes the reasons for the changes in the agricultural policy of the Bolsheviks towards Belarus at the turn of the 1920s-1930s. The author examines the direction and content of the transformational processes in the social sphere and in the economic behavior of the Belarusian peasantry. Furthermore, the development tendencies of the individual peasant household are identified. The author looks at the particularities of the marker behavior of the Belarusian peasantry as a factor in the closure of the New Economic Policy. The article presents an analysis of the dynamics of collectivization in the Belarusian Soviet Socialist Republic, forms, aims and results of Dekulakization. The author also explains the demographic losses resulting from the famine that hit Belarusian villages in 19291933. On the basis of a comparative study the author analyzes the dynamics and content of the socio-political transformations of Belarus at the turn of the 1920s-1930s, its specifics in comparison to other republics of the USSR. The historical-genetic method has allowed to trace the origins of the socio-economic contradictions in the Belarusian villages at the turn of the 1920s-1930s and their consequences. On the basis of a structural-functional analysis the author identifies the direction of the transformative processes in the Belarusian villages during the inter-war period. The author consequently comes to the conclusion that the individual development of peasant households during the second half on the 1920s came against significant difficulties, demonstrated above all in the decrease of the marketability of agricultural production. If individual peasant households revealed the tendency of an increased consumption, then through the kolkhoz system the part of bread production that was essential to the survival of 
peasant families was pumped out. This led to a mass famine in the Belarusian Soviet Socialist Republic and became one of the essential reasons for the slower growth in the population number during the first half of the 1930s. In 1933 (for the first time since the end of the First World War and the civil war) there was a decrease in the population number in the BSSR. In its survival strategy the Belarusian peasantry demonstrated a solidarity that was not dictated by party affiliation or social hierarchy. The development of education and an increase in the number of people from villages going to universities in the 1920s contributed to an increase in pro-peasant Belarusian sentiments, which among other factors determined a series of political processes in Belarus at the turn of the 1920s-1930s.

Key words: demographical processes, Soviet modernization, agrarian policy, collectivization, food security, market type behavior, social psychology, modernization, Belarusian village, transformational processes.

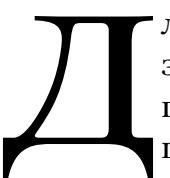

лительность и системность преобразований подчеркивают обычно через применение термина «трансформация», который включает, кроме институционально регулируемых действий, новые явления в мотивации и экономическом поведении, когда изменяются не только нормы (правовые и другие), но и социокультурная, а также технологическая структура общества. Если терминология трансформации в белорусской научной литературе в определенной степени разработана, то понятие «модернизация», предоставляющее более широкие возможности для полидисциплинарных исследований в отношении конкретных процессов советской истории Беларуси остается за пределами рассмотрения ученых. И. Д. Ковальченко подчеркивал, что «характеристика сущности тех или иных общественных отношений на основе той или иной теории всегда справедлива только в определенных исторических границах...» и настаивал на необходимости «синтеза идей и методов», а не механическом отбрасывании одних и замене их другими [1, 457].

В работах белорусских ученых по истории белорусской деревни второй половины XIX - начала XX в, пронализированы процессы социальной модернизации, вертикальной социальной мобильности крестьянства, характер изменений в сфере традиционной культуры и повседневной жизни [2]. Вместе с тем, исследования трансформационных процессов межвоенного периода советской истории крестьянства Беларуси не через противопоставление различных этапов и подходов, а с использованием историко-генетического и компаративного методов до настоящего времени не реализованы. Анализируя причины изменений в аграрной политике большевиков в Беларуси на рубеже 20-30-х гг. XX в., важно установить направленность и содержание трансформационных процессов в социальной сфере и экономическом поведении белорусского крестьянства, определить тенденции развития индивидуального крестьянского хозяйства на этом этапе. Динамика коллективизации в БССР, формы, цели и итоги раскулачивания могут быть оценены только с учетом демографических потерь в результате голода в белорусской деревне 1929-1933 гг. Возможности для такого углубления содержат не только многочисленные архивные материалы (прежде всего, бывших партийных архивов), но и новейшие публикации, осуществленные под руководством В.П.Данилова. Существенный потенциал представляют также данные статистических источников, прежде всего Всесоюзных переписей 1926,1937 и 1939 гг.

Рубеж 1920-30-х гг. традиционно оценивается как новый этап в трансформации белорусского общества, более того, нередко противопоставляется периоду середины 1920-х гг. Действительно ли изменения в аграрной политике были вызваны исключительно внешними обстоятельствами - внутрипартийной борьбой, или военной угрозой для страны? Влияние этих факторов на развитие национальных республик, в том числе Белорусской, исключать нельзя. В мае 1927 г. первого секретаря ЦК КП(б)Б А. И. Криницкого (очень последовательно проводившего в БССР установки Н. И. Бухарина) сменяет В. Г. Кнорин, уже имевший опыт противостояния национальным устремленням в Беларуси. Заявление В. Г. Кнорина при открытии ХІ съезда ЦК КП(б)Б 22 ноября 1927 г. свидетельствовало, что предчувствие возможной войны присутствовало не только в крестьянских слухах: «СССР победит, и в войне, которая произойдет, отвоюет право на социалистическое строительство в нашей стране» [3, л. 1]. Акцент на мобилизацию всех средств и сил у военного поколения воспринимался как важнейшая политическая задача. В 1928 г. руководство КП(б)Б возглавил Я. Б. Гамарник, стремившийся существенно ускорить процессы коллективизации. Его деятельность, по сути, предрешила разгром национальной интеллигенции и белорусского хозяйственного руководства, прежде всего круп- 


\section{Исторический журнал: научные исследования № 5 (35) • 2016}

DOI: $10.7256 / 2222-1972.2016 .5 .20208$

нейшего и наиболее значимого в БССР Наркомата земледелия во главе с Д. Ф. Прищеповым.

За период с 1923/24 по 1926/27 гг. валовая продукция сельского хозяйства БССР увеличилась на 23\%, преимущественно, за счет экстенсивных факторов - увеличения затрат живого труда, расширения землепользования, а эти ресурсы уже были исчерпаны [4, 192-219]. Крестьянство получило прирезку земли около 1 млн. десятин, но проблема аграрной перенаселенности для Беларуси оставалась очень острой, избыток рабочей силы доходил в республике до $40 \%$ [5, л. 112]. В начале 1927 г. нарком земледелия БССР Д.Ф.Прищепов подчеркивал, что деление крестьянских хозяйств достигло невероятных размеров. Каждый год количество мелких крестьянских хозяйств увеличивалось на 15000 , в то время как в первые годы после революции оно возрастало на 8 000» [6, л. 551]. Не наблюдалось и роста товарной продукции. Типичное середняцкое хозяйство оставалось наполовину натурально-потребительским. Возрастало потребление хлеба самими крестьянами, а также увеличивались затраты на корм скоту. «И не удивительно, - писал Д. Ф. Прищепов в 1928 г., - что современная наша товарность ниже, чем она была в дореволюционное время; безусловно, что на этом сказывается значительно увеличившееся после революции питание самого крестьянства. Такой рост сельского хозяйства, который пока что идет “в живот", нас удовлетворить не может» [7, 53-62]. Впрочем, на потребительский характер крестьянских хозяйств во многом влияли сложившиеся высокие цены на городские товары $[4,206]$. В условиях рыночного хозяйства нарушение пропорций вызывало к жизни применение административно-репрессивных санкций. Рыночный тип поведения имеет больше возможностей и перспектив, но, тем не менее, для его реализации необходимо выполнение ряда условий, как со стороны государства, так и со стороны индивида. Крестьяне были не самыми лучшими предпринимателями, отдавая предпочтение проверенным веками традиционным формам агрокультуры. М. В. Довнар-Запольский подчеркивал, что «белорус прежде всего земледелец, а в остальных делах не отличался предпринимательскими способностями» $[8,278]$. В донесениях НКВД в конце 1920-х гг. отмечалось, что «сознательные» крестьяне на стороне советской власти, поддерживают борьбу власти со «спекулянтами», утверждая что это способствует снижению цен [9, 687-688].
М. Д. Кондратьев еще в начале 1920 х гг., анализируя условия 1914-1916 гг., предсказал проблему, которая сложилась через 5-6 лет. Он подчеркивал, что увеличение потребления хлеба крестьянами и уменьшение производства высокотоварных «владельческих» (помещичьих) хозяйств способно вызвать кризис хлебного рынка (что в дальнейшем и произошло - X. C.) [10]. Высокотоварные помещичьи хозяйства в Беларуси не были заменены другими формами крупного сельскохозяйственного производства, в условиях дробления крестьянских хозяйств возрастал уровень их потребления. С 1926 г. БССР начинает ввозить зерна вдвое больше, чем в предыдущий год. Ситуацию усугубил хлебный кризис СССР, проявивший себя уже с начала $1927 / 28$ хозяйственного года, когда резко снизилось производство зерна на рынок. Повторились те же причины, которые сформировали предыдущий хлебный кризис 1916 г., но в мирных условиях, когда существенно возрастала доходная часть бюджета крестьянства по сравнению с расходной, и уменьшалось воздействие тех факторов, которые стимулировали крестьянство выбрасывать хлеб на рынок (в Беларуси - низкая стоимость зерна на рынке при высокой себестоимости собственного производства, развитие мясо-молочного животноводства, использование зерна на корм скоту).

Профессор А. В. Чаянов, вслед за А. М. Челинцевым, исследуя соотношение между ценами на мясо и корм скоту, пришел к выводу, на первый взгляд парадоксальному - эти цены обратно пропорциональны: чем дороже корм, тем дешевле мясо. Ведь домашние животные с доисторических времен выступали в качестве запасного капитала. В годы неурожаев и других катаклизмов крестьяне запускали в свои стада большое количество молодняка, чтобы в сложное для себя время использовать такого рода запасной фонд [11, 258]. В Беларуси во второй половине 1920-х гг. на эти процессы повлияли слухи о возможной войне, обесценивание денег и увеличение стоимости зерна и картофеля. В густонаселенных или малоземельных районах недостаток земли лишал крестьянскую семью возможности реализовать свою рабочую силу в условиях оптимальных форм организации труда. А. В. Чаянов утверждал, что крестьянская семья, которая не обладает достаточным запасом земли и средств производства, для полного использования своей работы в сельскохозяйственном предприятии располагает избыток своей работы в другом виде 
хозяйственной деятельности и выращивании таких сельскохозяйственных культур, которые требуют большего количества рабочих рук [11, 278]. Согласно данным «Перспективного плана развития сельского и лесного хозяйства...», трудоемкие культуры - лён, конопля, картофель гораздо были более распространены в беднейших хозяйствах, кормовые и зерновые - в зажиточных. Животноводческая продукция поставлялась на рынок преимущественно беднейшим и средним крестьянством [12]. Повышение цен на зерно в 1927-1928 гг. вызвало определенную панику на местном рынке. В 1928 г. поголовье свиней снизилось по сравнению с 1927 г. почти на $20 \%$ и составило $93 \%$ к уровню 1925 г. Закупочные цены на свинину кооперацией и государством определились как слишком низкие, частник перехватил инициативу в ее заготовке и, по-сути, диктовал рыночные цены [13, л. 10]. Именно беднейшее крестьянство и часть середняков в результате существенно потеряли во время «хлебного кризиса».

Д. Ф. Прищепов в 1928 г., вслед за В. А. Хауке, обратился к опыту Восточной Пруссии, где сохранение крупного хозяйства способствовало не только росту производства зерна, но и развитию кооперации, интенсификации сельского хозяйства, переработке ее продукции [7, 53-62]. Однако, он отстаивал сохраннение многообразия форм преобразований, делал ставку преимущественно на экономические методы хозяйствования. В условиях Союза продовольственная безопасность связывалась с функционированием всей экономики СССР. В его хлебопроизводящих районах одной из распространенных форм общественного производства становятся зерновые совхозы и ориентированные на зерновые культуры сельскохозяйственные артели. В Беларуси, в условиях недостатка техники и специализации в направлении мясо-молочного скотоводства, такие формы не получили значительного развития. Спорной оставалась и их социальная функция [14, л. 759].

В Беларуси в 1928 г. советским руководством предусматривались довольно реальные темпы роста количества коллективных объединений, планировалось охватить колхозами до 1933 г. не менее $6 \%$ крестьянских хозяйств [15, л. 54]. С середины 1929 г. даются установки на превращение целых сельсоветов в районы сплошной коллективизации. Создавались огромные (до 4 тыс. га) колхозы, управление которыми организовать было невозможно, равно как и вести интенсивное хозяйство [16, 159]. Уже весной 1929 г. в целом ряде районов имели место продовольственные трудности. В частности в д. Рудня Пальминского с/с Городокского района Витебской округа голодало более $70 \%$ семей, имелись случаи детской смертности [17, 879-880].

Вопреки решению XII съезда Компартии Беларуси, сентябрьский Пленум 1929 г не только не осудил искусственное форсирование количества коллективных хозяйств, но и закрепил это в качестве нового партийного решения [16, 159,161]. 1929 год был назван в статье И. В. Сталина годом «великого перелома». Между тем, на 1 октября 1929 г. процент коллективизации в БССР достиг только $3,6 \%$ (по СССР - 7,6\%) [18, 19]. В декабре 1929 г. в Советской Беларуси ставилась задача к осени 1933 г. достичь $80 \%$ коллективизации $[9,65]$. Однако, даже эти планы не удовлетворяли К. В. Гея, назначенного в январе 1930 г. первым секретарем КП(б)Б [19, л. 395]. Как результат, процент коллективизации в БССР почти в 2 раза превысил показатель по Украине (по состоянию на 20 января 1930 г. соответственно 27,0\% и 15,4\%) $[18,19]$. Отметим, что только 23 января 1930 г. был принят «Проект постановления Политбюро ЦК ВКП(б) о ликвидации кулачества как класса», подготовленный подкомиссией И. Д. Кабакова $[9,118]$.

Конфискованное имущество кулацких хозяйств должно было передаваться в неделимые фонды колхозов [20, л. 28]. Важнейшей целью раскулачивания являлось запугивание деревни, стремление сломать сопротивление тех ее групп, которые изначально выступали противниками коллективизации. Но, кроме главной цели, советское руководство преследовало и другие: хозяйственное освоение отдаленных малонаселенных или необжитых районов СССР, получение дешевой, если не бесплатной рабочей силы $[21,208]$. В Беларуси одной из важнейших особенностей явилось создание коллективов за счет имущества раскулаченных хозяйств. Так, если по СССР имущество раскулаченных получили 50,3\% колхозов, в РСФСР - 51,3\%, в Украине - 54,6\%, то в БССР эта цифра достигла $79,6 \%$. В результате стоимость имущества раскулаченных в составе неделимых фондов колхозов Белорусской Республики составила не менее $50 \%$ [18, 23]. По состоянию на 1 февраля 1930 г. процент коллективизации в Беларуси поднялся до $38,2 \%$ [9, 13], а на 1 марта 1930 г. - до 57,9\% (в Украине - 62,8\%).[22, 19]. Этому способство- 


\section{Исторический журнал: научные исследования № 5 (35) • 2016}

DOI: $10.7256 / 2222-1972.2016 .5 .20208$

вали репрессии в ходе коллективизации и аресты, которыми занимались все: бядняцко-середняцкие группы, сельские советы, уполномоченные, милиция, органы ОГПУ. Наибольшее количество арестов происходило в зерновых и приграничных районах СССР (также в БССР), где коллективизация осуществлялась ускоренными темпами [9, 13, 303-305].

Попытка снизить накал крестьянского сопротивления, предпринятая центральным руководством партии, вызвала существенный спад коллективизации [9, 365-370]. Согласно данным Посевбюро Наркомзема СССР о ходе коллективизации в СССР на 1 августа 1930 г., на протяжении с 20 января до 1 августа в 2 раза уменьшилось количество коллективов, и более чем в 5 раз количество крестьянских хозяйств в их составе. В результате процент коллективизации снизился с 27,2 до 10,0 [9, 574]. При этом три четверти крестьян вышли из коллективов даже без подачи заявления о такого рода действиях [23, л. 4]. Среди пассивных форм протеста крестьянства преобладали письма в различные инстанции [24, л. 13,14]. В мае 1930 г. контрольные структуры партии отмечали нарушение «добровольности коллективизации путем декретировання» $[25,86]$. Факты свидетельствуют, что подобного рода заявдения скорее принимались для формирования общественного мнения, нежели в качестве конкретных политических выводов. Выступавший на XIII съезде КП(б)Беларуси 30 мая 1930 г. Л. Н. Аронштам, который не только занимал должность начальника Политуправлення Белорусского военного округа, но и являлся членом Центральной контрольной комиссии ВКП(б) под смех в зале и подсказки самого К. В. Гея критиковал ЦК Компартии Беларуси: «У вас процент с 75 снизился до 13, а тов. Гей говорит открыто - до $11 \%$ (“10 с чем-то”)» [26, л. 58]. «В свое время идею раскулачивания, идею коллективизации предлагала оппозиция, - признавал К. В. Гей на этом съезде, - она не понимала того, что до тех пор, пока мы не создадим постоянной машинной базы, мы не можем стать на этот путь, ведь этот путь был бы авантюристическим путем» [26, л. 45]. При этом, выступавший после него нарком земледелия Ф. Н. Рачицкий вынужден был констатировать: «Наш тракторный парк составляет сегодня только 400 единиц на всю республику. То же и с другими сельскохозяйственными машинами» [26, л. 191].

В письме ЦК ВКП(б) от 24 сентября 1930 г. содержался призыв «к дальнейшему разверты- ванию прилива в колхозы» [9, 646-647]. Одновременно Бюро ЦК КП(б)б провозгласило необходимость «решительной борьбы за сохранение ленинских принципов в деле коллективизации» [27, л. 107]. Выступавшие на Пленуме КП(б)Беларуси 20-25 января 1931 г. отмечали: «Мы имеем ряде случаев, когда даже активные работники деревни в своих официальных выступлениях открыто говорят о том, что в этом году мы наделали много перегибов, так что теперь пусть приезжает кто-нибудь из центра, из района и коллективизирует, а мы - деревенская партячейка этого дела на себя взять не можем» [28, л. 213]. Нарком земледелия Ф. Н. Рачицкий, отметив, что для потребительских районов Советского Союза опредены цифры коллективизации в 20-25\%, а в животноводческих - 50\%, предложил 45\%: «для Беларуси эта цифра правильная, она не будет преувеличенной потому, что у нас тип сельского хозяйства развивается в сторону технических культур и животноводства» [28, л. 8, 13]. Для принуждения к вступлению в колхоз использовались все возможные способы: угрозы, обыски и др. В Паричском районе Бобруйского округа массово арестовывали тех, кто не захотел идти в колхоз. Так называемые «рабочие бригады» в Рогачевском районе арестовали 18 бедняков, в том числе 4-х беременных женщин [9, 301]. В сентябре 1931 г. ЦК КП(б)Б рапортовал о выполнении «поставленной партией задачи коллективизировать до 1 января 1931 г. $45 \%$ бедняцко-серядняцких хозяйств». По другим сведениям в БССР было колективизировано $47 \%$ крестьянских хозяйств, ряд районов отчитался о переходе к сплошной коллективизации и окончательной ликвидации кулачества как класса» [30, л. 73-75]. На 1 октября 1931 г. процент коллективизации по БССР составил 48,5\% (в УССР - 67,1\%; Казахстане - 63,0\%), на 10 февраля 1932 г. он вырос до 49,4\% [34, 282]. По сведениям же ОГПУ, цифры немного отличались: на 1 октября 1931 г. - 49,3\%, на 1 января 1932 г. $-50,4 \%$ [29, 282, 320].

Неопределенность такой социальной группы как «кулаки» формировала возможности для применения в качестве ее признаков самых различных оценок. В январе 1930 г. «кулацкие» элементы были разделены на 3 категории, однако никаких критериев деления на эти группы в обозначенном проекте не предлагалось [9, 123]. Раскулачивание происходило в жестких формах, в том числе в отношении женщин, стариков и детей. Так, в Хотимском сельсовете член 
ВКП(б), руководивший раскулачиванием, вынес на улицу и бросил в сани больного скарлатиной 4-х летнего ребенка, а другой участник раскулачивания взял себе старый полушубок, которым были прикрыты больные дети [9, 301]. Понимая, что подавляющую часть Красной армии составляет крестьянство, политическое управление Белорусского Военного округа внимательно следило за настроениями, выявлявшимися в письмах и разговорах красноармейцев [31, лл. 88-89]. Власти стремились к тому, чтобы не пострадали семьи, дети которых служат в Красной армии [9, 142]. Однако жалобы красноармейцам от родных и родителей все же доходили [32, л. 74].

Отдельной страницей жесткого противостояния рубежа 1920-1930-х гг. явилась высылка «кулаков». По протоколу ОГПУ 31 января 1930 г. предполагалось выслать из БССР в Сибирь 12 тыс. сельчан. После завершения наказания осужденные не могли возвращаться по месту жительства [9, 155]. Согласно приказу ОГПУ от 2 февраля 1930 г. из БССР предполагалось лишь «в первую очередь» выселить 6-7 тысяч семейств (таким образом, не менее 15-20 тыс. человек) [9, 165]. Республиканские органы власти с февраля 1930 г. вынуждены были согласовывать все свои действия в области выселения кулаков с ОГПУ. Коллективизация в Беларуси, по сути, представляла специфическую военную операцию. Уточнялось участие войск Белорусского военного округа в раскулачивании [9, 257], были задействованы также войска ОГПУ. В республику в мае 1930 г. было перемещено 259 отрядов, продолжительность их командировок обозначалась от нескольких дней до месяца [9, 405]. На закрытом заседании секретариата ЦК КП(б)Б в начале апреля 1930 г. было принято решение об «обеспечении оружием коммунистов, работающих на селе». Рекомендовалось организовать закупку соответствующего количества револьверов для «отъезжающих для работы в деревню студентов, окончивших в этом году Комвуз» [33, лл. 105, 530].

Сроки операции в начале мая 1930 г. были изменены, планировалось выселить 8 тыс. семей на Урал и в Северный край. Из БССР дополнительно к указанным 8 тысячам «в целях очищения пограничных районов от контрабандистских и бандитских элементов» выселялись еще 3579 одиночек «особого назначения» [9, 301; 412-413]. Для перемещения переселяемых кулацких семей были созданы в пунктах выгрузки приемные пункты (комендатуры), на которые возлагалась вся ответственность за прием әшелонов. По их данным было выселено в Северный край с БССР 4763 семей (22 810 человек) и в Уральскую область - 4468 семей (21 273 человека), на Дальний Восток - 183 семьи (1 787, включая одиночек «особого назначения»). На начало мая 1930 г. в эшелонах находилось еще 1792 одиночек «особого назначения» из Беларуси [9, 420-425].

Переполненые вагоны, недостаточное питание, непривычно суровый климат вызывали многочисленные заболевания и смертность, особенно среди детей. Власти опасались, что результатом может стать ухудшение эпидемиологического состояния в Северном крае и на Урале. Поэтому было разрешено высланных кулацких детей до 14-летнего возраста (с согласия родителей) выдавать родственникам для направления по месту прежнего жительства [9, 425]. Многие белорусские дети так и не увидели больше своих родителей. Воссоединению семей способствовала лишь несогласованность репрессивных органов $[9,523]$. Более 8 тысяч семей - это только кулаки так называемой «2-й категории». Что касается кулаков «3-й категории», то в их отношении принимались не столь радикальные действия [34, л. 530; 35, л. 263]. Вместе с тем, за счет земель кулацких хозяйств рекомендовалось укрупнять советские хозяйства [36, лл. 661-662].

По сведениям ОГПУ на 13 июня 1930 г. кулаков второй категории по БССР было раскулачено 13492 хозяйства, в том числе из указанного количества выслана 9701 семья $(72 \%)$ [9, 486]. В соответствии со справкой ОГПУ о выселенных кулаках 2-й и 3-й категории (после 20 мая 1930 г. лишений не проводилось), из БССР была выслана 9701 семья (47 392 человека) [9, 593]. По состоянию на 12 июня 1931 г. 1983 семьи (8 857 человек) находились в эшелонах по направлению в Уральскую область, кроме того, 1859 семей (8 219 человек) было вывезено, оставалось к выселению 1100 семей (5 000 человек) [9, 143]. Статистика по выселенным несколько отличается: по одним данным на начало ноября 1930 г. из БССР была выселена 9231 семья (44083 человек). Согласно другим сведениям, из пограничной зоны БССР дополнительно было выселено 3309 человек [29, 706]. В документах начала 1930-х имеются свидетельства того, что зажиточное состояние само по себе являлось основанием для обвинения, ибо судьи боялись, что их обвинят в правом уклоне. Комиссия под руко- 


\section{Исторический журнал: научные исследования № 5 (35) • 2016}

DOI: $10.7256 / 2222-1972.2016 .5 .20208$

водством А. А. Сольца (возможно адного из немногих лиц, кто еще об этом говорил) отмечала, что “органы Прокуратуры не всегда достаточно решительно и своевременно реагируют на нарушение законности» [37].

В конце января 1932 г. происходят изменения в руководстве ЦК КП(б)Б - первым секретарем назначается - Н. Ф. Гикало. С точки зрения личных качеств, по мнению В. М. Морозовой, новый первый секретарь насколько был романтиком в молодости, настолько прагматиком и жестким управлецем - в зрелые годы, «он приехал в Беларусь как специалист по национальной интеллигенции и взял под личный контроль творческую элиту» [38]. Выступая на XIV съезде КП(б)Б 20 января 1932 г. Н. Ф. Гикало заявил: «Я, к сожалению, белорусским языком не владею». В ответ Н. М. Голодед заметил: «Мы Вам полгода льготных дадим» [39, л. 62]. Однако, с 1933 г. обозначились уже другие процессы. Надежды Н. М. Голодеда и ряда других белорусских руководителей на то, что изменения в партийном руководстве повлияют на содержание политики в Беларуси, не оправдались [40,57].

Несмотря на рост показателей в процентах, распад колхозов продолжался и в 1932 г. $[29,422]$. Он нередко происходил путем стихийных выступлений; чаще всего инициаторами являлись женщины [41]. В этот период над стратегической целью советской модернизации (создание крупных машинизированных хозяйств) возобладала тактическая - обеспечение города хлебом, который должен был в сжатые сроки создать такую базу и подобного рода технику. В июле 1930 г. БССР было установлено задание в 12 млн. пудов [9, 548], однако уже в сентябре 1930 г. (по мнению властей, из-за хорошего урожая) план был увеличен на 1 млн. пудов, выполнение которого происходило неудовлетворительно. Согласно данным ОГПУ за 1 квартал заготовительного сезона 1930 г., БССР существенно отставала по темпам хлебозаготовок $(16,4 \%)$ $[9,668]$. В следующем году цифра была снижена до 10,5 млн. пудов, но в 1932 г. задание опять увеличили [29, 206, 261]. Кроме того, 1200 тыс. пудов предлагалось засыпать в семенной фонд в БССР на 1932 г. Колхозы также выплачивали натуроплату МТС [34, 786]. Уже в начале 1930-х гг. в СССР получали преимущественную часть зерна по заготовкам именно от колхозов: в 1931/32 гг. 14,7 млн т (против 6,66 т от индивидуальных хозяйств), в 1932/33 гг. - 12,24 (против 2,64 млн. т) $[29,857]$. Таким образом, колхозная форма про- являлась как определенный механизм реквизиции зерна.

В 1932-1933 гг. партийные и государственные структуры БССР неоднократно заслушивали вопросы продовольственного положения в республике и периодически просили помощи у центрального руководства [42, 294; 43, л.154]. 4 и 5 апреля 1932 г. начались волнения в Борисове, вызванные введением новых норм хлеба. Наряду с уступками были усилены карательные действия, а также усилена ответственность за поставки мясных и молочных продуктов [43, лл. 39-40,170,185]. В докладной записке секретарю ЦК КП(б)Б Н. Ф. Гикало приводились свидетельства «кулацкого саботажа», о настроениях на селе: что «народ восстанет», «политика партии на селе неправильная. С крестьянина выкачивают все, что только можно, несмотря на то, что у него уже ничего не осталось...» [43, л. 395]. Отмечалось, что директива партии о том,чтобы единоличные хозяйства сдавали с 1 га земельной площади не менее, чем колхозы не выполнена [43, л. 6].

Если индивидуальное крестьянское хозяйство выявило тенденцию к увеличению потребления, то через колхозную систему выкачивалась иногда даже та часть хлеба, которая была необходима для выживания крестьянской семьи [44, л. 198]. Согласно справке секретно-политического отдела ОГПУ о ходе коллективизации и массовых выступлениях крестьянства в 1931 г. - январе-марте 1932 г., продовольственные трудности в Беларуси нарастали. Обращалось внимание на то, что в Дриссенском пограничном районе не имели хлеба 23 колхоза. 40 семей голодали в отдельных колхозах - Минского пригородного района, по несколько семей в Петриковском и Краснослободском районах [29, 320]. На XVII съезде партии Н. Ф. Гикало подробно рассказывал том, как за 20 дней декабря 1932 г. был выполнен план по хлебозаготовкам [45].

В 1933 г. голод распространился в южной части Белорусской ССР. Им были охвачены девять сельских советов. До середины июня 1933 г. в Ельском и Наровлянском районах от голода умерли 130 человек, а количество опухших достигало 230 человек. Голодом была затронута и центральная часть БССР - некоторые колхозы Минского района, значительная часть Пуховичского и некоторых других районов [42, 283, 284, 295]. Продовольственные трудности стали причиной ряда выступлений в городах Беларуси [46, 157-161]. Период с лета 1933 г. иногда определя- 
ется как «неонэп», однако в Советскую Беларусь он, как и нэп, пришел с опозданием [47, 278]. Наряду с мероприятиями по организационному укреплению колхозов, акцент на их количественном росте сохранялся. Согласно справке Госплана СССР, на 1 июля 1933 г. по БССР он составил 50,3; на 1 июля 1934 г. - 55,3, а на 1 июля 1935 г. планировалось достичь $64 \%$ [47].

В условиях реквизиций зерна и голода на селе отмечалась тенденция, когда подсобное хозяйство оставалось источником снабжения хлебом. Согласно сведениям о состоянии подготовки к заготовительной кампании по БССР фактическая заготовка хлеба в кампанию 1932/33 г. составила - 127,8 тыс. т. На 1933 г. план резко повышался (до 204,5 тыс. т., в том числе совхозам - 3 тыс. т.; колхозам зоны МТС - 28,1 т; колхозам МТС - 58,2 т.; единоличникам - 115,3 т.). В указанные плановые цифры 204,5 т. не входило поступление хлеба от МТС по натуроплате. Почти в два раза возрастали объемы и по заготовке картофеля - 792,9 тыс. тонн (в 19321933 гг. - 423 тыс. тонн. [48, л. 3 - 6]. По итогам года оказалось, что если принять заготовки 1929 г. за 100\%, то хлебопроизводящие области сдали в 1933 г. 151\%, а «потребляющие» (например, Западная область, БССР, Ленинградская область, Московская область) - 205\%). На 1934 г. были обозначены такие же цифры. Из 9,5 млн. пудов по БССР 6,0 млн. пудов должны были сдать колхозы $[47,66]$.

В борьбе за права и землю, белорусское крестьянство выявило, прежде всего, свою солидарность, зачастую вне зависимости от партийной принадлежности и социальной иерархии. В Минском районе работники сельсовета, узнав об арестах, начали выдавать справки зажиточным крестьянам о «благонадежности», чем спасли часть из них, разрешив уехать. Недоверие между властью и сельчанами достигло таких масштабов, что на деревню были направлены специальные информаторы ЦК, которые периодически присылали свои донесения с мест. Они жаловались на «неудовлетворительную» работу местной милиции и судов, которые «прикрываясь отсутствием инструкций» - не в должной степени требовательно относились к таким действиям крестьян. Один из иинформаторов» отмечал, что в результате его деятельности были отданы под суд 300 «заговорщиков», «кулаков-зажиточников», а работу местных руководящих работников называл не иначе, как «гнилым либерализмом». Информаторы ЦК свидетельствовали о многочисленных случаях, когда коммунисты «прикрывают своих». Студенты-комсомольцы из Минска, которых направили «способствовать делу коллективизации» просились из деревни, мотивируя свое ходатайство трудностью учебы. Приводился пример, когда кандидат в члены партии заявил: «Очень жестоко, нужно подходить по человечески». А местные комсомольцы говорили, что если дальше так пойдет дело, то лучше они лишатся своих комсомольских билетов» [49]. В руководстве партии прекрасно понимали, что развитие образования, рост числа выходцев из деревни в вузах в 1920-е гг. способствовал росту прокрестьянских, белорусских настроений. В донесениях НКВД отмечалось: «Интеллигенция национальных республик отличается от «российской» интеллигенции - она существенно более активная и более близка деревне по своей социальной природе и своим политическим настроениям, так как в большинстве своем вышла из деревни и сохранила с ней тесную связь» $[17,815]$. Именно это способствовало целому ряду политических процессов в Беларуси на рубеже 20-30-х гг. XX в.

Неурожай «второго хлеба» - картофеля предопределил, что население Беларуси в 1933 г. оказалось в условиях еще большего голода, чем в 1931-1932 гг. Особенно сложная ситуация сложилась в восточной части Беларуси. По зоне обслуживания Климовичской МТС четверть колхозов имели менее 1 кг питания на каждого колхозника (а еще же их семьи!). Во многих колхозах не осталось картофеля даже на семена. Несмотря на получение продовольственной ссуды (на колхозную семью не больше 40 кг), ситуация в начале апреля - начале мая резко обострилась. «Во многих колхозах применяют в пищу крапиву, траву, листья липы и лозы, - отмечалось в донесении политотдела Климовичской MTC. - В колхозе имени Кагановича колхозники съели корову, которая погибла от сибирской язвы. В колхозе «Красный край» от недоедания многие колхозники болеют тифом. В колхозе имени Криницкого, имени Калинина, имени Кагановича, «Парижская коммуна» есть много опухших. Голодают даже лучшие ударники». Из 4200 семей, которые находились в колхозах Климовичской МТС, более половины нуждались в продовольственной помощи, но ее по сведениям на 25 июня оказано не было. Примерно такое же положение сложилось и в Плещеницкой зоне МТС. «Продовольственное положение колхозников зоны деятельности МТС очень тяжелое, - 


\section{Исторический журнал: научные исследования № 5 (35) • 2016}

DOI: $10.7256 / 2222-1972.2016 .5 .20208$

отмечается в документе. По ряду колхозов питаются исключительно травой. Контрреволюционный элемент использует продовольственные затруднения, активизируя свою деятельность» $[47,279]$. Зимой 1933-1934 гг. крестьяне начали массовый забой скота, на что немедленно отреагировала Прокуратура СССР. При этом его осуществляли как колхозники, так и рабочие совхозов, а также единоличники $[47,66]$. Убой скота белорусские крестьяне начали уже с 1929 г., в результате на 1 февраля 1932 г. по сравнению с 1 июля 1928 г. количество крупного рогатого скота сократилось с 2184 тыс. до 1447,7 тыс., свиней - с 2290, 8 до 1437, 6, овец с 3448, 9 тыс. к 2099,7, а на 1 января 1933 г. уменьшилось по сравнению с показателями 1928 г. в 2-3 раза. На 1 января 1934 г. количество коров составило 50\% от состояния на 1 июля 1928 г., свиней - около $25 \%$, овец - менее $20 \%$ [50, л. 10].

Историки уже обращали внимание на замедление роста численности населения в первой половине 1930-х гг., причины которого видятся в социально экономических составляющих, прежде всего, в голоде. Интересным источником в этом отношении являются «Помесячные данные о рождаемости и смертности населения по городским и сельским местностям БССР в 1932, 1933 и 1934 гг.» [51]. Они позволяют проследить показатели рождаемости и смертности за 1932-1934 гг. (тот период, когда эти сведения не были под контролем НКВД) [52]. Анализируя сведения помесячных данных, можно заметить не только погодовые изменения, но и сезонные. Заметно, что смертность возрастала в феврале -апреле и далее снижалась в мае - июне. Рост ее в июле - августе компенсировался снижением смертности с октября по декабрь. Учитывая преобладание сельского населения, сезонность работы и ее результатов, можно видеть влияние на деревню природно-климатических явлений и ситуации с питанием. Погодовые сведения дают возможность отметить, что наиболее опасная демографическая ситуация сложилась именно в 1933 г. Смертность за этот год возросла примерно на $83 \%$ (почти вдвое) по сравнению с предыдущим 1932 г. Рождаемость в следующем 1934 г. снизилась более чем на $10 \%$ по сравнению с 1933 г. и на 22\% по сравнению с 1932 г. Для 1933 г. характерно (впервые за послевоенные годы) снижение численности населения БССР. При этом такая ситуация наблюдалась в первую очередь в городе. На селе, благодаря высокой рождаемости, снижения численности населения не произошло. Однако, прирост населения с 1932 по 1934 г. уменьшился более чем вдвое, достигая в отдельные месяцы близких к нулю показателей [52].

Таким образом, к концу 1920-х гг., как и утверждали советские историки, индивидуальное крестьянское хозяйство, деревня в целом нуждались в существенном реформировании. Для модернизации и повышения обороноспособности страны необходимы были средства, взять их можно было только у крестьянства. Недостаток машинной техники вызывал потребность в большом количестве дешевых рабочих рук. При этом, сплошная коллективизация сельского хозяйства в Беларуси в условиях развития мясо-молочного животноводства и сельскохозяйственных культур, выращивание которых на данном этапе не могло быть механизировано, уже изначально не создавала никаких преимуществ. Сочетание кооперированных форм мелких и крупных хозяйств на селе, интегрирующих сбыт и переработку своей продукции в условиях унитарных подходов к трансформации обществ с различными традициями и экономическим поведением, не было осуществлено. Однако партийное руководство в БССР реализовало ускоренный проект трансформации общества, имевший катастрофические последствия как для общественного производства, так и для судеб белорусского крестьянства.

\section{Библиография:}

1. Ковальченко И. Д. Сущность и особенности общественно-исторического развития (Заметки о необходимости обновленных подходов) // Он же. Методы исторического исследования: Отделение историко-филологических наук. 2-е изд., доп. М. : Наука, 2003. Приложение. С. 454-481., С. 26-40.

2. Голубеў В. Ф. Сельская абшчына ў Беларусі XVI-XVIII стст. Мінск : Беларус. навука, 2008.407 с.; Бяспалая М. А. Эканамічнае і сацыякультурнае развіццё беларускай вёскі ў гады нэпа (1921-1927). Мінск : Беларус. дзярж. ун т культуры і мастацтваў, 2009. 325 с.; Каханоўскі, А. Г. Сацыяльная трансфармацыя беларускага грамадства (1861-1914 гг.). Мінск: БДУ.2013, 335 с.; Токць, С. М. Сацыяльныя і культурныя працэсы ў беларускай вёсцы ў другой палове XIX - пачатку XX ст. / С.М.Токць. - Мінск : ДІКСТ БДУ, 2015. - 328 с.

3. Стенографический отчет XI съезда ЦК КП(б)Белорусии 22-28 ноября 1927 г. 813 л. // Национальный архив Республики Беларусь. Ф. 4п. Оп. 1. Д. 3090. 
4. Маслов П. П. Развитие сельского хозяйства до и после революции. Из архива партии. //Известия ЦК КПСС. - 1989. №10. С.192-219.

5. Документы о состоянии сельского хозяйства и очередных задачах аграрной политики в БССР (докладная записка, информация, выводы и др.). 12 февраля-24 марта 1925 г. 375 л. // Национальный архив Республики Беларусь. Ф. 4п. Оп. 1. Д. 2295.

6. Стенограмма Х съезда КП(б)Белоруссии. 03.011927-20.01.1927 гг. На 706 л. +2 // Национальный архив Республики Беларусь. Ф. 4п. Оп. 1.Д. 3083.

7. Прышчэпаў Зьм. Задачы рэканструкцыі сельскай гаспадаркі ў сёлетнюю пасеўкампанію // Савецкае будаўніцтва. 1928. № 3-4. C. 53-62

8. Довнар-Запольский, М. В. Исследования и статьи. Т. 1 : Этнография и социология, обычное право, статистика, белорусская письменность. Киев, 1909.

9. Трагедия советской деревни. Коллективизация и раскулачивание. 1927-1939 : в 5 т. Т. 2 : Ноябрь 1929 - декабрь 1930 / под ред. В. Данилова, Р. Маннинг, Л. Виолы ; отв. ред. Н. Ивницкий. М. : РОССПЭН, 2000. 927 с.

10. Кондратьев Н. Д. Рынок хлебов и его регулирование во время войны и революции / отв. ред.акад. Л. И. Абалкин. М : Наука, 1994. 487 с.

11. Чаянов А. В. Крестьянское хозяйство. Избр. тр. / редкол. сер. : Л. И. Абалкин (пред.) [и др.].М. : Экономика, 1989. 492 с. (Экон. наследие).

12. Прищепов Д. Мероприятия по восстановлению сельского хозяйства Белоруссии // Вперед.1924. № 2.

13. Постановление, распоряжение и протоколы заседаний СНК БССР и ЭКОСО, докладная записка президиума Минского окрисполкома о проведении контрактации семенных культур в округе в 1927-1928 гг. и переписка с Наркомторгом БССР и Белсельсоюзом о снабжении Белоруссии сельскохозяйственными машинами, об организации птицеводческих хозяйств в колхозах и совхозах республики и др. // Национальный архив Республики Беларусь. Ф. 18. Оп. 3. Д. 21.

14. Стенограмма XI съезда КП(б)Б от 22-29 ноября 1927 г. 813 л. // Национальный архив Республики Беларусь Ф. 4п. Оп. 1. Д. 3090.

15. Постановления ЦИК и Совнаркома БССР о мероприятиях по развитию колхозного строительства, выделению участков земли для колхозов, их землеустройству, доклад Наркомзема БССР о положении совхозов и колхозов, списки колхозов по округам // Национальный архив Республики Беларусь. Ф. 48. Оп. 1. Д. 4002.

16. Стэнограма і рэзолюцыі верасеньскага Пленуму ЦК КП(б)Б (5-8 верасьня 1929 г.). Менск, 1929. 382 с.

17. Советская деревня глазами ВЧК - ОГПУ - НКВД. 1918-1939. Документы и материалы: в 4 т. / под ред. А. Берелович, В. Данилова. М.: РОССПЭН, 2000. Т. 2.1923-1929 гг. ; 1168 с.

18. Ивницкий Н. А. Судьба раскулаченных в СССР. - М.: Собрание, 2004. 296 с.

19. Протоколы № 1-5 заседаний Бюро ЦК КП(б), документы к ним. № 35-45. 27 сентября -23 ноября 1929 г., на 372 л. // Национальный архив Республики Беларусь. Ф. 4п. Оп. 1. Д. 4328.

20. Протоколы и постановления СНК и Совета Министров СССР (подлинники). 1923-1950 гг. // Государственный архив Российской Федерации. Р 5446. Оп. 1. Д. 53.

21. Ивницкий Н. А. Коллективизация и раскулачивание (начало 30-х годов). М. : ИНТЕРПРАКС, 1994. 269 с.

22. Ивницкий Н.А. Репрессивная политика советской власти в деревне (1928-1933 гг.). РАН. Ин-т рос. истории, Университет г. Торонто (Канада). М., 2000. 350 с.

23. Обзор крестьянских писем о политическом настроении, присланных в редакцию «Крестьянской газеты». 7-20 апреля 1930 г. // Государственный архив Российской Федерации. Ф. 5446. Оп. 55. Д. 1975.

24. Письмо в редакцию «Крестьянской газеты» из Орши // Государственный архив Российской Федерации. Ф. 5446.0 Оп. 55. Д. 1974.

25. Справаздача ЦК КП(б)Б да ХІІ з’езду КП(б)Б (студзень 1929 - май 1930). Менск, 1930. 163 с.

26. Стенограмма XIII съезда КП(б)Б от 30-31 мая 1930 г. 234 л. // Национальный архив Республики Беларусь. Ф. 4п. Оп. 1. Д. 4730.

27. Усім райкомам КП(б)Б. Сакрэтна // Национальный архив Республики Беларусь. Ф. 4п. Оп. 3. Д. 4764.

28. Стенограмма и заседания пленума ЦК КП(б)Б от 20-26 января 1931 г. 289 л. // Национальный архив Республики Беларусь. Ф. 4п. Оп. 1. Д. 5102.

29. Трагедия советской деревни. Коллективизация и раскулачивание. 1927-1939. Док. и материалы : в 5 т. / под ред. В. Данилова [и др.]. М. : РОССПЭН, 2001. Т. 3 : Конец 1930-1933. 1008 с.

30. Протоколы заседаний секретариата ЦК КП(б)Б, документы к ним. 21 сентября - 1 октября 1931 г., на 321 л. // Национальный архив Республики Беларусь. Ф. 4п. Оп. 1. Д. 5.

31. Приказ Политического управления Белорусского Военного округа // Национальный архив Республики Беларусь. Ф. 4п. Оп. 1. Д. 4700.

32. Обзор Политического управления Белорусского военного округа № 2.0 работе и настроениях вокруг решения партии о ликвидации кулака как класса // Национальный архив Республики Беларусь. Ф. 4. Оп. 1. Д. 4700.

33. Пратакол № 31 зачынянага паседжаньня сакратарыяту ЦК КП(б)Б AД 2/IV 30 Г // Национальный архив Республики Беларусь. Ф. 4п. Оп. 1. Д. 4331.

34. Бюро Гомельскага акруговага камітэта КП(б) па пытаньню аб расьсяленьні і высяленьні кулакоў 3 й катэгорыі // Национальный архив Республики Беларусь. Ф. 4п. Оп. 1. Д. 4446.

35. Пастанова Бюро Менскага Акруговага Камітэту КП(б)Б аб кулаках 3 й катэгорыі // Национальный архив Республики Беларусь.Ф. 4п. Оп. 1. Д. 4448.

36. Пратакол № 78 Унечарговага пасяджэньня Бюро Аршанскага Акругкома КП(б)Б ад 6 га красавіка 1930 г. // Национальный архив Республики Беларусь. Ф. 4п. Оп. 1. Д. 4452.

37. Стенограмма XIV съезда КП(б)б. 26.01-29.01.1932 г. // Национальный архив Республики Беларусь. Ф. 4п. Оп. 1. Д. 5591.

38. Морозова О. М. Николай Федорович Гикало //Вопросы истории. 2011. № 9. С. 37-57, С. 54

39. Стенограмма XIV съезда КП(б)Бел. (3-й экз.) 20.01.1932-26.01.1932. 286 л. // Национальный архив Республики Беларусь. Ф. 4п. Оп. 1. Д. 5590. 


\section{Исторический журнал: научные исследования № 5 (35) • 2016}

DOI: $10.7256 / 2222-1972.2016 .5 .20208$

40. Платонов Р. П. Беларусь в межвоенный период: страницы политической истории в свете архивных источников. Минск: БелНДІДАС, 2001. 282 с.

41. Материалы о развале колхозов и выходе из них за первый квартал 1932 года // Национальный архив Республики Беларусь. Ф. 4п. Оп. 1. Д. 6302

42. Гісторыя Беларусі : у 6 т. / А. Вабішчэвіч [і інш.] ; рэдкал. : М. Касцюк (гал. рэд.) [і інш.]. Мінск : Экаперспектыва, 2006. Т. 5 : Беларусь у 1917-1925 гг. 613 с.

43. Сакрэтны аддзел. Пастановы і выпіска. Лютага 1932 г. - жнівень 1933. 435 л. // Национальный архив Республики Беларусь. Ф. 4п. Оп. 1. Д. 5549.

44. Протоколы заседаний секретариата ЦК КП(б)Б, документы к ним. 14 февраля - 25 марта 1931 г., на 364 л. // Национальный архив Республики Беларусь. Ф. 4п. Оп. 1. Д. 5118.

45. XVII съезд ВКП(б). 26 января-10 февраля 1934 г. Стенографический отчет. Заседание третье (27 января 1934 г., вечернее). Продолжение прений по Отчетному докладу товарища Сталина о работе ЦК ВКП(б):Речь товарища Гикало // Электронный доступ: http://www.hrono.info/dokum/1934vkpb17/3_3.php.

46. Докладная записка т. Гикало о волнениях в гор. Борисове в связи с уменьшением норм выдачи хлеба и снятием части населения со снабжения // Голод в СССР. 1929-1934 : в 3 т. М. : МФД, 2011. Т. 1 : 1929 - июль 1932. Кн. 2.560 с. (Россия. ХХ век. Документы).

47. Трагедия советской деревни. Коллективизация и раскулачивание. 1927-1939. Документы и материалы : в 5 т. / под ред. В. Данилова, Р. Маннинг, Л. Виолы. М. : РОССПЭН, 2002. Т. 4 : 1934-1936. 1056 с.

48. Докладные, письма, сводки... янв. 1933 - июнь 1935 г. 181+2 л. // Национальный архив Республики Беларусь. Ф. 4п. Оп. 1. Д. 6988

49. Информационные сводки оргинструкторского отдела ЦК КП(б)Б о внутрипартийном настроении населения в районах в связи с проведением хлебозаготовок, среди рабочих предприятий г. Минска, ходе разъяснительной работы по политике повышения цен. 1932-1933 гг. 36 л. // Национальный архив Республики Беларусь. Ф. 4п. Оп. 1. Д. 5996.

50. Протокол № 1 заседания Комиссии ЦК КП(б)Б по животноводству от 3 февраля 1933 г. о порядке работы Комиссии, [стенограмма] совещания [при ЦК КП(б)Б] от 25 марта 1934 г. о состоянии животноводства в БССР. 183 г. // Национальный архив Республики Беларусь. Ф. 4п. Оп. 1. Д 7083.

51. Ходзін, С. М. Беларуская вёска ў міжваенны час: шляхі і формы савецкай мадэрнізацыі (1921-1939) / С. М. Ходзін. Мінск : БДУ, 2014. - 240 с Ходзін, С. Н. Дэмаграфічныя змены ў сельскіх населеных пунктах БССР (1921-1939 гг.) / С.Н. Ходин // Гістарычна-археалагічны зборнік. Вып. 30. - Мінск, «Беларуская навука», 2015. С. 171-176.

52. Помесячные данные о рождаемости и смертности населения РСФСР, УССР и БССР за 1932, 1933, 1934 гг. [Электронный pecypc]. URL: http://istmat.info/node/18141/ (дата обращения: 21.10.2013.).

\section{References (transliterated):}

1. Koval'chenko I. D. Sushchnost' i osobennosti obshchestvenno-istoricheskogo razvitiya (Zametki o neobkhodimosti obnovlennykh podkhodov) // On zhe. Metody istoricheskogo issledovaniya: Otdelenie istoriko-filologicheskikh nauk. 2-e izd., dop. M. : Nauka, 2003. Prilozhenie. S. 454-481., S. 26-40.

2. Golubey̆ V. F. Sel'skaya abshchyna y̆ Belarusi XVI-XVIII stst. Minsk : Belarus. navuka, 2008.407 s.; Byaspalaya M. A. Ekanamichnae i satsyyakul'turnae razvitstse belaruskai veski y̆ gady nepa (1921-1927). Minsk : Belarus. dzyarzh. un t kul'tury i mastatstvay̆, 2009. 325 s.; Kakhanoy̆ski, A. G. Satsyyal'naya transfarmatsyya belaruskaga gramadstva (1861-1914 gg.). Minsk: BDU.2013, 335 s.; Tokts', S. M. Satsyyal'nyya i kul'turnyya pratsesy y̆ belaruskai vestsy y̆ drugoi palove KhIKh - pachatku KhKh st. / S.M.Tokts'. - Minsk : DIKST BDU, 2015. - $328 \mathrm{~s}$

3. Stenograficheskii otchet KhI s"ezda TsK KP(b)Belorusii 22-28 noyabrya 1927 g. 813 l. // Natsional'nyi arkhiv Respubliki Belarus'. F. 4p. Op. 1. D. 3090.

4. Maslov P. P. Razvitie sel'skogo khozyaistva do i posle revolyutsii. Iz arkhiva partii. //Izvestiya TsK KPSS. - 1989. №10. S.192-219.

5. Dokumenty o sostoyanii sel'skogo khozyaistva i ocherednykh zadachakh agrarnoi politiki v BSSR (dokladnaya zapiska, informatsiya, vyvody i dr.). 12 fevralya-24 marta 1925 g. 375 l. // Natsional'nyi arkhiv Respubliki Belarus'. F. 4p. Op. 1. D. 2295.

6. Stenogramma Kh s"ezda KP(b)Belorussii. 03.011927-20.01.1927 gg. Na 706 1. +2 // Natsional'nyi arkhiv Respubliki Belarus'. F. 4p. Op. 1. D. 3083.

7. Pryshchepay̆ Z'm. Zadachy rekanstruktsyi sel'skai gaspadarki y̆ seletnyuyu pasey̆kampaniyu // Savetskae buday̆nitstva. 1928. № 3-4. S. 53-62

8. Dovnar-Zapol'skii, M. V. Issledovaniya i stat'i. T. 1 : Etnografiya i sotsiologiya, obychnoe pravo, statistika, belorusskaya pis'mennost'. Kiev, 1909.

9. Tragediya sovetskoi derevni. Kollektivizatsiya i raskulachivanie. 1927-1939 : v 5 t. T. 2 : Noyabr' 1929 - dekabr' 1930 / pod red. V. Danilova, R. Manning, L. Violy ; otv. red. N. Ivnitskii. M. : ROSSPEN, 2000. 927 s.

10. Kondrat'ev N. D. Rynok khlebov i ego regulirovanie vo vremya voiny i revolyutsii / otv. red.akad. L. I. Abalkin. M : Nauka, 1994.487 s.

11. Chayanov A. V. Krest'yanskoe khozyaistvo. Izbr. tr. / redkol. ser. : L. I. Abalkin (pred.) [i dr.].M. : Ekonomika, 1989.492 s. (Ekon. nasledie).

12. Prishchepov D. Meropriyatiya po vosstanovleniyu sel'skogo khozyaistva Belorussii // Vpered.1924. № 2.

13. Postanovlenie, rasporyazhenie i protokoly zasedanii SNK BSSR i EKOSO, dokladnaya zapiska prezidiuma Minskogo okrispolkoma o provedenii kontraktatsii semennykh kul'tur v okruge v 1927-1928 gg. i perepiska s Narkomtorgom BSSR i Belsel'soyuzom o snabzhenii Belorussii sel'skokhozyaistvennymi mashinami, ob organizatsii ptitsevodcheskikh khozyaistv $\mathrm{v}$ kolkhozakh i sovkhozakh respubliki i dr. // Natsional'nyi arkhiv Respubliki Belarus'. F. 18. Op. 3. D. 21.

14. Stenogramma XI s"ezda KP(b)B ot 22-29 noyabrya 1927 g. 813 l. // Natsional'nyi arkhiv Respubliki Belarus' F. 4p. Op. 1. D. 3090.

15. Postanovleniya TsIK i Sovnarkoma BSSR o meropriyatiyakh po razvitiyu kolkhoznogo stroitel'stva, vydeleniyu uchastkov zemli dlya kolkhozov, ikh zemleustroistvu, doklad Narkomzema BSSR o polozhenii sovkhozov i kolkhozov, spiski kolkhozov po okrugam // Natsional'nyi arkhiv Respubliki Belarus'. F. 48. 0p. 1. D. 4002.

16. Stenograma i rezolyutsyi verasen'skaga Plenumu TsK KP(b)B (5-8 veras'nya 1929 g.). Mensk, 1929. 382 s. 


\section{Социальная история}

DOI: $10.7256 / 2222-1972.2016 .5 .20208$

17. Sovetskaya derevnya glazami VChK - OGPU - NKVD. 1918-1939. Dokumenty i materialy: v 4 t. / pod red. A. Berelovich, V. Danilova. M.: ROSSPEN, 2000. T. 2. 1923-1929 gg. ; 1168 s.

18. Ivnitskii N. A. Sud'ba raskulachennykh v SSSR. - M.: Sobranie, 2004. $296 \mathrm{s.}$

19. Protokoly № 1-5 zasedanii Byuro TsK KP(b), dokumenty k nim. № 35-45. 27 sentyabrya -23 noyabrya 1929 g., na 372 l. // Natsional'nyi arkhiv Respubliki Belarus'. F. 4p. Op. 1. D. 4328.

20. Protokoly i postanovleniya SNK i Soveta Ministrov SSSR (podlinniki). 1923-1950 gg. // Gosudarstvennyi arkhiv Rossiiskoi Federatsii. R 5446. Op. 1. D. 53.

21. Ivnitskii N. A. Kollektivizatsiya i raskulachivanie (nachalo 30-kh godov). M. : INTERPRAKS, 1994. $269 \mathrm{~s}$.

22. Ivnitskii N.A. Repressivnaya politika sovetskoi vlasti v derevne (1928-1933 gg.). RAN. In-t ros. istorii, Universitet g. Toronto (Kanada). M., 2000. $350 \mathrm{~s}$.

23. Obzor krest'yanskikh pisem o politicheskom nastroenii, prislannykh v redaktsiyu «Krest'yanskoi gazety». 7-20 aprelya 1930 g. // Gosudarstvennyi arkhiv Rossiiskoi Federatsii. F. 5446. Op. 55. D. 1975.

24. Pis'mo v redaktsiyu «Krest'yanskoi gazety» iz Orshi // Gosudarstvennyi arkhiv Rossiiskoi Federatsii. F. 5446. Op. 55. D. 1974.

25. Spravazdacha TsK KP(b)B da XII z'ezdu KP(b)B (studzen' 1929 - mai 1930). Mensk, 1930.163 s.

26. Stenogramma XIII s"ezda KP(b)B ot 30-31 maya 1930 g. 234 l. // Natsional'nyi arkhiv Respubliki Belarus'. F. 4p. Op. 1. D. 4730.

27. Usim raikomam KP(b)B. Sakretna // Natsional'nyi arkhiv Respubliki Belarus'. F. 4p. Op. 3. D. 4764.

28. Stenogramma i zasedaniya plenuma TsK KP(b)B ot 20-26 yanvarya 1931 g. 289 l. // Natsional'nyi arkhiv Respubliki Belarus'. F. 4p. Op. 1. D. 5102.

29. Tragediya sovetskoi derevni. Kollektivizatsiya i raskulachivanie. 1927-1939. Dok. i materialy : v 5 t. / pod red. V. Danilova [i dr.]. M. : ROSSPEN, 2001. T. 3 : Konets 1930-1933. 1008 s.

30. Protokoly zasedanii sekretariata TsK KP(b)B, dokumenty k nim. 21 sentyabrya - 1 oktyabrya 1931 g., na 321 l. // Natsional'nyi arkhiv Respubliki Belarus'. F. 4p. Op. 1. D. 5.

31. Prikaz Politicheskogo upravleniya Belorusskogo Voennogo okruga // Natsional'nyi arkhiv Respubliki Belarus'. F. 4p. Op. 1. D. 4700 .

32. Obzor Politicheskogo upravleniya Belorusskogo voennogo okruga № 2 . 0 rabote i nastroeniyakh vokrug resheniya partii o likvidatsii kulaka kak klassa // Natsional'nyi arkhiv Respubliki Belarus'. F. 4. Op. 1. D. 4700.

33. Pratakol № 31 zachynyanaga pasedzhan'nya sakrataryyatu TsK KP(b)B AD 2/IV 30 G // Natsional'nyi arkhiv Respubliki Belarus'. F. 4p. Op. 1. D. 4331.

34. Byuro Gomel'skaga akrugovaga kamiteta KP(b) pa pytan'nyu ab ras'syalen'ni i vysyalen'ni kulakoy̆ 3 i kategoryi // Natsional'nyi arkhiv Respubliki Belarus'. F. 4p. Op. 1. D. 4446.

35. Pastanova Byuro Menskaga Akrugovaga Kamitetu KP(b)B ab kulakakh 3 i kategoryi // Natsional'nyi arkhiv Respubliki Belarus'. F. 4p. Op. 1. D. 4448.

36. Pratakol № 78 Unechargovaga pasyadzhen'nya Byuro Arshanskaga Akrugkoma KP(b)B ad 6 ga krasavika 1930 g. // Natsional'nyi arkhiv Respubliki Belarus'. F. 4p. Op. 1. D. 4452.

37. Stenogramma XIV s"ezda KP(b)b. 26.01-29.01.1932 g. // Natsional'nyi arkhiv Respubliki Belarus'. F. 4p. Op. 1. D. 5591.

38. Morozova 0. M. Nikolai Fedorovich Gikalo //Voprosy istorii. 2011. № 9. S. 37-57, S. 54

39. Stenogramma XIV s"ezda KP(b)Bel. (3-i ekz.) 20.01.1932-26.01.1932. 286 1. // Natsional'nyi arkhiv Respubliki Belarus'. F. 4p. Op. 1. D. 5590.

40. Platonov R. P. Belarus' v mezhvoennyi period: stranitsy politicheskoi istorii v svete arkhivnykh istochnikov. Minsk : BelNDIDAS, 2001. $282 \mathrm{~s}$.

41. Materialy o razvale kolkhozov i vykhode iz nikh za pervyi kvartal 1932 goda // Natsional'nyi arkhiv Respubliki Belarus'. F. 4p. Op. 1. D. 6302

42. Gistoryya Belarusi : u 6 t. / A. Vabishchevich [i insh.] ; redkal. : M. Kastsyuk (gal. red.) [i insh.]. Minsk : Ekaperspektyva, 2006. T. 5 : Belarus' u 1917-1925 gg. 613 s.

43. Sakretny addzel. Pastanovy i vypiska. Lyutaga 1932 g. - zhniven' 1933. 435 l. // Natsional'nyi arkhiv Respubliki Belarus'. F. 4p. Op. 1. D. 5549.

44. Protokoly zasedanii sekretariata TsK KP(b)B, dokumenty k nim. 14 fevralya - 25 marta 1931 g., na 364 l. // Natsional'nyi arkhiv Respubliki Belarus'. F. 4p. Op. 1. D. 5118.

45. XVII s"ezd VKP(b). 26 yanvarya-10 fevralya 1934 g. Stenograficheskii otchet. Zasedanie tret'e (27 yanvarya 1934 g., vechernee). Prodolzhenie prenii po Otchetnomu dokladu tovarishcha Stalina o rabote TsK VKP(b):Rech' tovarishcha Gikalo // Elektronnyi dostup: http://www.hrono.info/dokum/1934vkpb17/3_3.php.

46. Dokladnaya zapiska t. Gikalo o volneniyakh v gor. Borisove v svyazi s umen'sheniem norm vydachi khleba i snyatiem chasti naseleniya so snabzheniya // Golod v SSSR. 1929-1934 : v 3 t. M. : MFD, 2011. T. 1 : 1929 - iyul' 1932. Kn. 2. 560 s. (Rossiya. XX vek. Dokumenty).

47. Tragediya sovetskoi derevni. Kollektivizatsiya i raskulachivanie. 1927-1939. Dokumenty i materialy : v 5 t. / pod red. V. Danilova, R. Manning, L. Violy. M. : ROSSPEN, 2002. T. 4 : 1934-1936. 1056 s.

48. Dokladnye, pis'ma, svodki... yanv. 1933 - iyun' 1935 g. 181+2 l. // Natsional'nyi arkhiv Respubliki Belarus'. F. 4p. Op. 1. D. 6988.

49. Informatsionnye svodki orginstruktorskogo otdela TsK KP(b)B o vnutripartiinom nastroenii naseleniya v raionakh v svyazi s provedeniem khlebozagotovok, sredi rabochikh predpriyatii g. Minska, khode raz"yasnitel'noi raboty po politike povysheniya tsen. 1932-1933 gg. 36 l. // Natsional'nyi arkhiv Respubliki Belarus'. F. 4p. Op. 1. D. 5996.

50. Protokol № 1 zasedaniya Komissii TsK KP(b)B po zhivotnovodstvu ot 3 fevralya 1933 g. o poryadke raboty Komissii, [stenogramma] soveshchaniya [pri TsK KP(b)B] ot 25 marta 1934 g. o sostoyanii zhivotnovodstva v BSSR. 183 g. // Natsional'nyi arkhiv Respubliki Belarus'. F. 4p. Op. 1. D 7083.

51. Khodzin, S. M. Belaruskaya veska y̆ mizhvaenny chas: shlyakhi i formy savetskai madernizatsyi (1921-1939) / S. M. Khodzin. Minsk : BDU, 2014. - 240 s Khodzin, S. N. Demagrafichnyya zmeny y̆ sel'skikh naselenykh punktakh BSSR (1921-1939 gg.) / S.N. Khodin // Gistarychna-arkhealagichny zbornik. Vyp. 30. - Minsk, «Belaruskaya navuka», 2015. S. 171-176.

52. Pomesyachnye dannye o rozhdaemosti i smertnosti naseleniya RSFSR, USSR i BSSR za 1932, 1933, 1934 gg. [Elektronnyi resurs]. URL: http://istmat.info/node/18141/ (data obrashcheniya: 21.10.2013.). 